Jurnal Layanan Masyarakat (Journal of Public Service), vol 4 no 2 Tahun 2020, halaman 326-338

ISSN 2580-8680, e-ISSN 2722-239X

\title{
PEMANFAATAN DIGITAL MARKETING UNTUK PENGEMBANGAN BISNIS PADA KARANG TARUNA PERMATA ALAM PERMAI GEDANGAN SIDOARJO
}

\section{DIGITAL MARKETING FOR BUSINESS DEVELOPMENT IN KARANG TARUNA PERMATA ALAM PERMAI GEDANGAN SIDOARJO}

\author{
Rudi Santoso ${ }^{1}$, Achmad Yanu Alif Fianto ${ }^{2}$, Novan Ardianto ${ }^{3}$ \\ ${ }^{1,2,3}$ Universitas Dinamika, Surabaya, Indonesia \\ email: rudis@dinamika.ac.id
}

\begin{abstract}
Nowadays, the development of social media and marketplaces as part of information technology contributes to business activities. This development has also changed the pattern and map of market competition to become much more competitive. Therefore, mastery of the use of social media and marketplaces is important and strategic that every business actor must have. However, this is in contrast to business people who are still pioneering or have just started their business, such as the youth at Karang Taruna Permata Alam Permai Gedangan Sidoarjo. With minimal knowledge and insight about social media and marketplaces it can hinder them from developing their start-up businesses. Therefore, this community service activity aims to increase the insight and knowledge of the Karang Taruna Permata Alam Permai Gedangan Sidoarjo in the use of social media and marketplaces to develop business. The methods used in the implementation of community service activities include training and mentoring related to increasing knowledge and insight. Knowledge and insight referred to in this activity is the use of information technology. This information technology can be used to develop a wider marketing reach. This activity has been going well and has an important contribution in improving the quality of the Permata Alam Permai Gedangan Sidoarjo Youth Organization which has been able to apply social media and marketplaces as part of the digital marketing tool. The use of this media can also encourage increased sales due to the development of exposure of the products being sold.
\end{abstract}

Keywords: Digital Marketing, Marketplace, Social Media

\begin{abstract}
abstrak
Dewasa ini perkembangan media sosial dan marketplace sebagai bagian dari teknologi informasi berkontribusi dalam aktifitas bisnis. Perkembangan tersebut juga telah mengubah pola dan peta persaingan pasar menjadi jauh lebih kompetitif. Oleh karena itu penguasaan penggunaan media sosial dan marketplace menjadi penting dan strategis yang harus dimiliki oleh setiap pelaku bisnis. Namun hal ini kontras dengan pelaku-pelaku bisnis yang masih merintis atau baru memulai bisnisnya seperti para pemuda di Karang Taruna Permata Alam Permai Gedangan Sidoarjo. Dengan pengetahuan dan wawasan yang minim tentang media sosial dan marketplace dapat menghambat mereka dalam mengembangkan bisnis yang dirintis. Oleh karena itu, kegiatan pengabdian kepada Masyarakat ini bertujuan untuk meningkatkan wawasan dan pengetahuan Karang Taruna Permata Alam Permai Gedangan Sidoarjo dalam penggunaan media sosial dan marketplace untuk mengembangkan bisnis. Metode yang digunakan dalam pelaksanaan kegiatan pengabdian kepada masyarakat mencakup pelatihan dan pendampingan terkait dengan peningkatan pengetahuan dan wawasan. Pengetahuan dan wawasan yang dimaksudkan pada kegiatan ini adalah pemanfaatann teknologi informasi. Teknologi informasi ini bisa digunakan untuk mengembangkan jangkauan
\end{abstract}


pemasaran yang lebih luas. Kegiatan ini telah berjalan dengan baik dan memiliki kontribusi penting dalam peningkatan kualitas Karang Taruna Permata Alam Permai Gedangan Sidoarjo yang telah mampu mengaplikasikan media sosial dan marketplace sebagai bagian dari digital marketing tool. Penggunaan media ini juga dapat mendorong peningkatan penjualan karena adanya perkembangan eksposur dari produk-produk yang dijual.

Kata kunci: Digital Marketing, Marketplace, Media Sosial

\section{PENDAHULUAN}

Media sosial telah bertransformasi menjadi saluran komunikasi paling populer saat ini. Penggunaan media sosial selain untuk melakukan interaksi berkirim pesan juga digunakan untuk berjejaring. Jejaring sosial yang berkembang saat ini adalah blog, forum diskusi, dunia virtual dan audio visual. Perkembangan selanjutnya, media sosial digunakan sebagai tempat menunjukkan ekspresi diri, membentuk citra diri, aktualisasi dan eksistensi diri. Hal ini dapat terjadi karena media sosial menyediakan kemudahan penggunanya untuk berpartisipasi secara aktif.

Keunggulan teknologi informasi berbasis media sosial (medsos) ini semakin memperkuat posisi pebisnis dalam memenangkan persaingan di era industry 4.0. Penguasaan penggunaan medsos dan marketplace sebagai sarana digital marketing tool dapat meningkatkan penjualan (Pradiani 2017). Dalam konteks bisnis, informasi diposisikan sangat penting dan strategis. Hal ini terkait dengan kecepatan penyebaran informasi produk ke pelanggan. Kecepatan ini telah mengubah hampir di seluruh tatanan bisnis. Salah satu alat penyampaian informasi tersebut adalah dengan menggunakan media sosial sebagai bentuk dari digital marketing. Bisnis konvensional customer to customer (C2C) mengharuskan pertemuan dan kontak fisik. Namun bisnis berbasis online (digital) pertemuan tersebut berlangsung di dunia maya. Sehingga model bisnis konvensional yang tidak efisien tersebut mengalami perubahan sebagai bentuk adaptasi perkembangan media informasi saat ini (Asri \& Megawati 2018).

Penggunaan situs jejaring sebagai media komunikasi digital telah jamak dilakukan di Indonesia. Hal ini juga mengingat bahwa Indonesia adalah negara dengan pengguna situs jejaring terbesar keempat setelah India, USA, dan Brazil (Santoso 2019). Media sosial ini bukan lagi dipakai sebagai alat komunikasi atau interaksi. Jejaring sosial telah bertransformasi menjadi digital marketing tool dan digital selling. Penggunaan jejaring sosial sebagai alat promosi penjualan telah terbukti meningkatkan penjualan (Puspitarini \& Nuraeni 2019) juga sekaligus meningkatkan kesadaran merek (Akbar, 2018; Barri \& Saerang, 2017; Tarigan \& Tritama 2016).

Selain media sosial, marketplace telah menjadi tempat penjualan yang paling efisien dan efektif di era digital. Penelitian yang dilakukan oleh (Susanto et.al. 2020) mengungkapkan bahwa media sosial FaceBook (FB) terbukti telah meningkatkan penjualan online dengan peningkatan aktifitas promosi menggunakan digital marketing. Hal ini sebagai ekses dari penggunaan internet sebagai media pertukaran informasi, katalog produk, media promosi, deskripsi produk dan lain-lain (Yuliana 2000). Sementara itu keunggulan lain yang dimiliki oleh media sosial adalah meminimalisir batasan manusia dalam berinteraksi sosial (Fianto 2020b, 2020a; Ikawira \& Fianto 2014; Jafar et.al. 2014; Lauwrentius 2015; Pinasti et.al. 
2015; Santoso et.al. 2019; Santoso \& Fianto 2020). Pengguna jejaring sosial mampu melakukan komunikasi dari manapun dan kapanpun. Keunggulan ini harusnya bisa dimanfaatkan untuk perluasan jaringan bisnis, perdagangan, selain menambah pertemanan. Hal tersebut juga bisa dimanfaatkan sebagai media promosi produk dari unit usaha mikro dan menengah.

Sekelompok pemuda yang tergabung dalam Karang Taruna Permata Alam Permai Gedangan Sidoarjo adalah salah satu organisasi di kampung yang sedang mengelola bisnis skala mikro. Usaha yang dirintis kelompok Karang Taruna ini bergerak di bidang makanan ringan. Usaha kecil ini memiliki partner dalam mendistribusikan produknya yaitu retail dan outlet. Dari sisi retail, bisnis ini telah menggandeng minimarket di sekitar lingkungan mereka sebagai mitra distribusinya. Sementara itu dari sisi outlet, usaha kecil ini menggandeng beberapa outlet sentra kuliner Surabaya.

Permasalahan yang dihadapi oleh kelompok Karang Taruna Alam Permai adalah mereka belum memahami betul siapa saja yang terlibat atau terkait dengan bisnisnya. Hal ini mengakibatkan kegiatan operasional yang dilakukan tidak berjalan efektif. Selain itu keberadaan produk usaha kecil ini tidak banyak diketahui oleh masyarakat. Kedua, pemasaran yang dilakukan oleh Karang Taruna ini masih sebatas offline dari mulut ke mulut (words of mouth). Selain itu, mereka hanya fokus pada kegiatan pameran yang diadakan pada saat-saat event tertentu saja.

Permasalahan lain yang dialami oleh kelompok usaha dari Karang Taruna ini adalah terkait dengan latar belakang pendidikan yang homogen dan bukan dari latar belakang teknologi informasi. Hal ini berekses pada tingkat pengetahuan dan wawasan tentang teknologi informasi sangat minim. Sehingga Karang Taruna ini tidak mampu memanfaatkan keunggulan yang dimiliki oleh teknologi informasi untuk menunjang bisnisnya. Selain itu, ketersediaan infrastruktur online untuk menyelenggarakan bisnis melalui internet seperti situs jejaring sosial, marketplace, dan channel video nyaris tidak ada.

Dari permasalahan tersebut, karang taruna Permata Alam Permai belum mampu mengembangkan bisnis dengan menggunakan media digital. Padahal penggunakan media sosial dan digital marketing mampu meningkatkan penjualan hasil home industry (Ratna Gumilang, 2019). Disamping meningkatkan penjualan, penggunaan media sosial berbasis e-marketing juga mampu meningkatkan daya saing produk (Intan et.al. 2019). Sementara itu penggunaan marketplace sebagai sarana jual adalah upaya meningkatkan pemasaran dan penjualan (Susanto et.al. 2020).

\section{METODE PENGABDIAN MASYARAKAT}

Metode yang digunakan dalam kegiatan ini adalah pelatihan dan pendampingan terkait dengan peningkatan pengetahuan dan wawasan. Pengetahuan dan wawasan yang dimaksudkan pada kegiatan ini adalah pemanfaatann teknologi informasi. Teknologi informasi ini bisa digunakan untuk mengembangkan jangkauan pemasaran yang lebih luas. Selain itu, kegiatan ini juga melakukan penataran dalam bentuk daring tetang pemanfaatan media sosial (FB dan IG) untuk kemudian mengintegrasikannya dengan marketplace 
(Shopee dan Tokopedia). Indikator ketercapaian kegiatan ini beragam. Berikut ini adalah tabel indikator ketercapaian kegiatan:

Tabel 1 Metode Kegiatan dan Indikator Capaian

\begin{tabular}{|c|c|c|}
\hline No. & Nama Kegiatan & Indikator Capaian \\
\hline 1 & Pembuatan akun Medsos dan Marketplace & $\begin{array}{l}\text { Tersedia media sosial dan marketplace } \\
\text { berupa akun FaceBook, Instagram, } \\
\text { Shopee dan Tokopedia. }\end{array}$ \\
\hline 2 & Pelatihan dasar penggunaan internet & $\begin{array}{l}\text { Mitra memahami dan menerapkan hasil } \\
\text { pelatihan penggunaan internet. }\end{array}$ \\
\hline 3 & $\begin{array}{l}\text { Pelatihan penggunaan corporate page } \\
\text { medsos }\end{array}$ & $\begin{array}{l}\text { Mitra memahami dan menerapkan hasil } \\
\text { pelatihan pelatihan penggunaan } \\
\text { corporate page media sosial. }\end{array}$ \\
\hline 4 & $\begin{array}{l}\text { Pelatihan desain unggahan content meedos } \\
\text { dan marketplace }\end{array}$ & $\begin{array}{l}\text { Mitra memiliki kemampuan desain } \\
\text { konten. }\end{array}$ \\
\hline
\end{tabular}

\section{HASIL DAN PEMBAHASAN}

Berdasarkan analisis situasi yang telah dilakukan, Karang Taruna Permata Alam Permai membutuhkan strategi Pemasaran yang terdiri atas content marketing, digital promotion, social media integration, dan toko online. Berikut ini adalah beberapa Langkah yang telah dilakukan:

\section{Strategi Penjualan}

Pertama, Target Pasar. Target pasar Bisnis UKM Karang Taruna Permata Alam Permai adalah remaja, dewasa dan orang berpenghasilan menengah ke bawah. Hal ini karena produk yang Dijual adalah produk dengan harga pada segment tersebut.

Kedua, Nilai Produk. Bisnis yang dilakukan oleh Karan Taruna Permata Alam Permai mempunyai value (nilai) yang menjadi keyword adalah berkualitas, terjamin Kesehatan, bikin nagih. Keyword berkualitas diartikan sebagai hal yang bernilai, dimana apa yang didapatkan sesuai dengan yang dibayarkan. Pada akhirnya nilai produk dianggap menjadi istimewa. Nilai terjamin Kesehatan karena produk makanan yang dihasilkan tanpa bahan pengawet dan bergizi sehingga nilai produk ini menyehatkan. Terakhir, bikin nagih merupakan nilai dari produk yang mampu mendorong pelanggan untuk terus menginginkannya. Hal ini mendorong pelanggan untuk melakukan pembelian ulang.

Ketiga, Relationship. Salah satu luaran yang akan dicapai dari kegiatan ini adalah pelatihan mengenai dasar-dasar teknologi informasi dan cara-cara menyusun strategi manajemen komunikasi. Tool yang digunakan dalam hal ini adalah akun media sosial. Akun media sosial digunakan. Kegiatan diawali dengan pembuatan akun media sosial Instagram (IG), Facebook (FB) dan Youtube. Kedua akun media sosial ini digunakan sebagai tempat promosi dan media komunikasi bisnis berbasis online. Akun IG diatur langsung untuk kepentingan Bisnis Karang Taruna Alam Permai Sidoarjo. Akun official ini dibuat spesifik 
agar dapat dimanfaatkan sebagai media komunikasi pemasaran terpusat bisnis online Anggota Karang Taruna tersebut. Akun ini juga terhubung dengan akun media sosial lainnya yaitu Youtube. Youtube menjadi salah satu pilihan untuk media promosi bisnis Anggota Karang Taruna. Ketiga, adalah akun Facebook, di mana akun ini digunakan sebagai halaman fanspage konsumen bisnis Anggota Karang Taruna Alam Permai. Ketiga akun media sosial ini telah digunakan Anggota Karang Taruna untuk memajang segala bisnis online.

Produk yang paling banyak dan menjadi primadona adalah produk makanan ringan. Produk ini menjadi produk andalan Anggota Karang Taruna. Akun ini telah diikuti oleh lebih dari 1000 (seribu) pengikut/follower, dengan total unggahan 54 unggahan produk. Begitu juga dengan akun official Facebook Karang Taruna Alam Permai dikhususkan untuk memajang produk bisnis online anggota. Akun ini telah diikuti oleh lebih dari 100 pengikut dengan total unggahan materi tak kurang dari 75 materi. Akun yang telah dibuat sejak program kegiatan PKM ini berlangsung, telah menghasilkan beberapa transaksi. Akun ini dikelola oleh admin khusus yang bertugas untuk menggunggah dan mengkomunikasikan produk makanan ringan kepada konsumen. Selain itu, medsos ini juga digunakan sebagai media publikasi kegiatan Karang Taruna.

Keempat, Channel. Channel merupakan saluran yang umum digunakan oleh perusahaan atau pebisnis untuk mengkomunikasikan dan mendistribusikan produknya. Agar bisnis online Anggota Karang Taruna tersebut lebih luas menyasar konsumen, media penjualannya pun sudah menyasar marketplace. Marketplace yang digunakan Karang Taruna dalam mewadahi bisnis online anggotanya adalah Tokopedia dan Shopee. Kedua marketplace ini digunakan sebagai alat untuk menjangkau pasar. Keduanya merupakan marketplace paling popular di Indonesia dengan nilai transaksi paling besar. Akun yang dibuat 3 (tiga) bulan lalu ini telah mengunggah 86 (delapan puluh enam) produk dan diikuti tak kurang dari 300 (tiga ratus) pengikut. Selain produk makanan ringan yang ditawarkan, akun ini juga mengunggah produk hasil kerajinan Tangan seperti bros, dan bahan aplikasi kerajinan.

Sementara itu, akun tokopedia yang dibuat mengkhususkan pada produk makanan ringan khas Sidoarjo. Akun yang dibuat sejak Mei 2020 ini masih mengunggah 9 produknya. Akun ini Belum maksimal digunakan karena admin akun tersebut masih fokus untuk memperbesar pasar di Shopee. Meskipun akun Tokopedia tidak seaktif Shopee, namun hasil penjualan kedua channel ini nyaris sama dengan komposisi $46 \%$ Tokopedia dan 54\% menggunakan Shopee. Pemilihan kedua marketplace ini bukan tanpa alasan. Kedua marketplace ini adalah tempat jualan yang paling aktif di Indonesia. Hal ini juga pernah diungkapkan dalam penelitian (Mbete \& Tanamal, 2020) yang mengungkapkan bahwa shopee dan Tokopedia merupakan marketplace paling diminati oleh pebisinis UKM dan sekaligus pengguna (Pembeli).

Implementasi marketplace sebagai sarana jual produk Bisnis Karang Taruna Permata Alam Permai membuahkan hasil peningkatan omset jualan. Selama 3 (tiga) bulan sejak implementasi Mei - Juli 2020, nilai omset penjualan terus merangkak naik. Rerata kenaikan penjualan mingguan cukup signifikan jika dibandingkan pada periode sebelum menggunakan marketplace dan medsos. Pada masa sebelum menggunakan marketplace dan 
medsos, penjualan dilakukan secara ofline. Rerata penjualan pun masih di seputar satu jutaan. Apalagi Ketika masa pandemic tiba, penjualan relative mengalami penurunan.

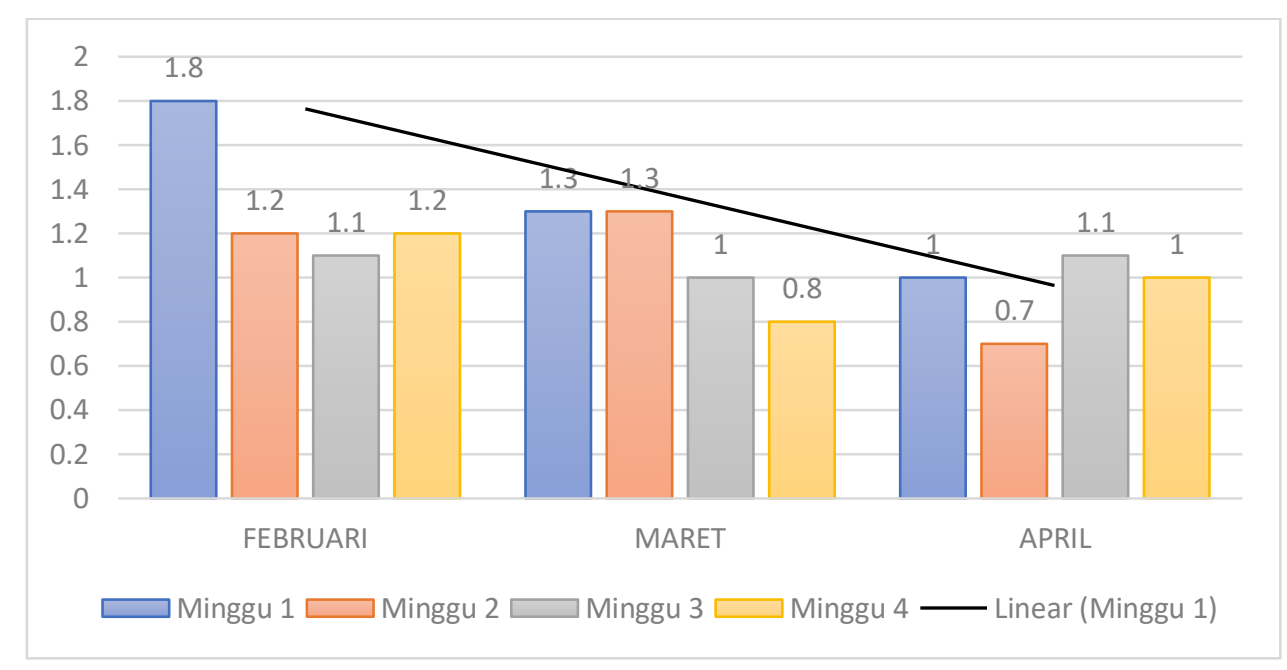

Grafik 1 Omset Penjualan Offline

Grafik di atas menunjukkan kondisi penjualan Mitra sebelum menggunakan aplikasi marketplace dan medsos. Ada tren penuruan di setiap minggu. Hal ini selain tidak ada event kegiatan pameran, masa pandemi mengakibatkan penjualan juga ikut menurun. Bisnis ini mampu bertahan karena produk mereka dikonsumsi oleh masyarakat sekitar.

Namun kondisi berangsur membaik ketika mitra mengaplikasikan marketplace dan media sosial sebagai sarana penjualan. Grafik di bawah ini menujukkan tren kenaikan penjualan yang cukup signifikan.

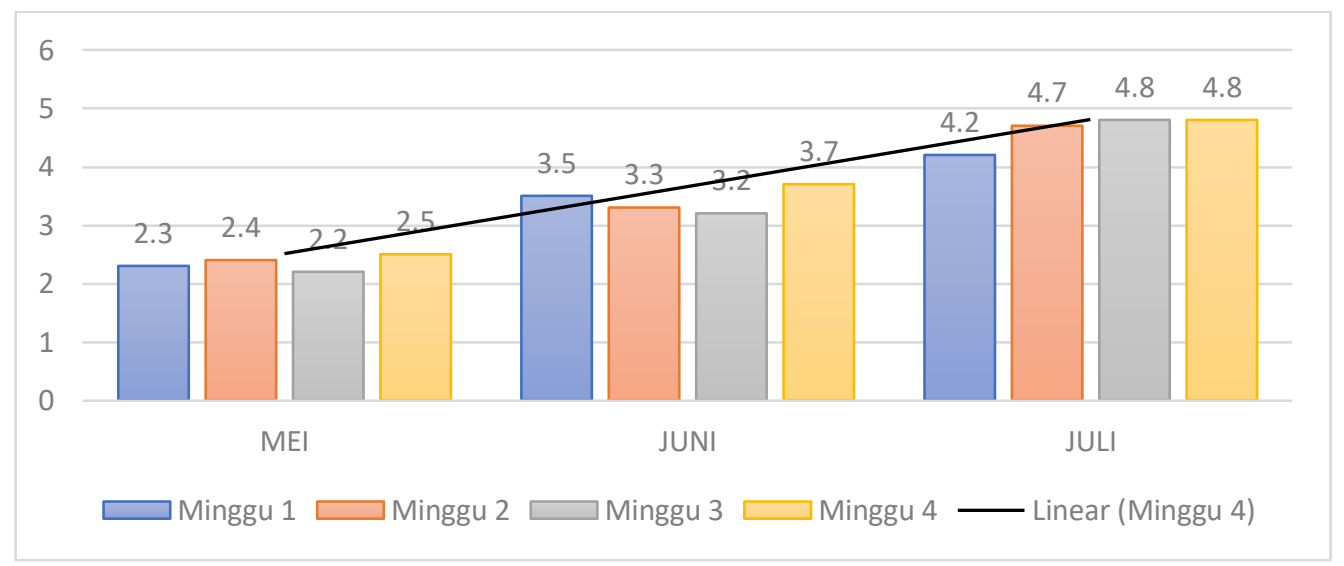

Grafik 2 Omset Penjualan Online 
Nilai penjualan rerata bulanan naik 1 juta. Bahkan pada minggu terakhir di bulan Juli 2020, omset penjualan hampir mencapai 5 juta. Jika omset penjualan dibandingkan pada bulanbulan sebelum penerapan aplikasi ini terlihat total kenaikan adalah $400 \%$. Hal ini mengacu pada rerata penjualan pada masa offline yang masih berkisar 1 juta kemudian naik menjadi hampir 5juta (4,8juta).

Kondisi penjualan yang naik ini menunjukkan bahwa target pencapaian kegiatan ini bukan saja pada penerapan Teknologi Informasi sebagai sarana jual. Lebih dari itu outcame yang dicapai adalah adanya peningkatan penjualan dari sisi omset. Hal ini membuktikan juga asumsi bahwa penggunaan media sosial dapat meningkatkan penjualan (Fauziyah, 2018; Sunarti et.al. 2019). Peningkatan pendapat tersebut selain karena efisiensi perluasan potensi pasar juga karena jalur distribusi yang lebih singkat. Hal ini senada dengan yang pernah diteliti oleh (Apriadi \& Arie Yandi Saputra 2016) yang menegaskan bahwa penggunaan marketplace dapat mempercepat barang diterima oleh konsumen tanpa kontak lansung dengan penjual.

Selain efisiensi tersebut, dari sisi pembeli juga akan lebih cepat memutuskan untuk melakukan pembelian ketika melihat produk melalui m edia sosial. Pembeli atau konsumen bisnis Karang Taruna ini biasa melakukan riset atau mencari-cari produk yang sesuai dengan keinginan mereka melalui media sosial. Maka penggunaan media sosial sebagai alat digital marketing telah terbukti efisien dalam meningkatkan awareness dan keputusan membeli oleh konsumen. Hal ini juga senada dengan penelitian (Batee 2019; Puspitarini \& Nuraeni 2019; Sulaksono \& Zakaria 2020; Yulia 2018) yang mengungkapkan bahwa media sosial sangat efektif digunakan sebagai sarana marketing and selling di era digital.

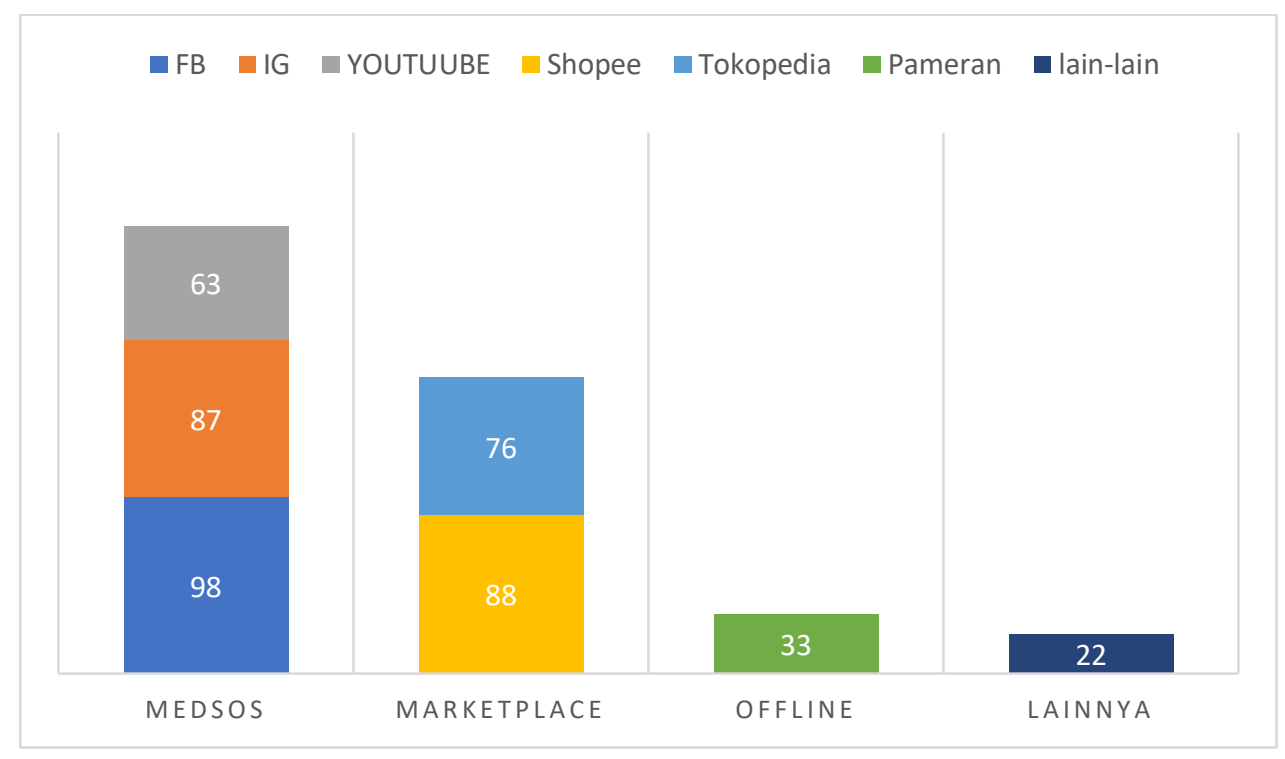

Grafik 3 Saluran Promosi \& Penjualan

Berdasarkan pada Grafik 3 di atas menunjukkan bahwa FaceBook adalah media sosial yang paling banyak diakses pelanggan dalam mendapatkan informasi produk. Rerata 98 orang 
mengakses saluran ini untuk mendapatkan informasi produk diikuti oleh saluran Instagram yang diakses rerata 87 orang. Sementara itu 63 orang lainnya menggunakan YouTube untuk mendapatkan informasi produk. Facebook masih menjadi saluran media nomor satu untuk promosi dan penjualan. Hal tersebut juga pernah diungkapkan oleh (Hidayat et al., 2017) bahwa Facebook digunakan sebagai sarana promosi karena nyaris tidak ada biaya yang dikeluarkan.

Sementara itu penggunaan marketplace shopee sebagai media belanja oleh pelanggan bisnis Karang Taruna menduduki urutan pertama dengan total akses penggunaan 88 pengguna. Penelitian serupa pernah dilakukan oleh (Ridwan et.al. 2020) yang mengungkapkan bahwa faktor sukses Shopee menjadi marketplace terbaik adalah kepercayaan konsumen. Tokopedia yang menjadi salah satu marketplace unicorn Indonesia digunakan oleh pelanggan bisnis Karang Taruna Permata Alam Permai untuk bertransaksi. Pengguna transaksi ini mencapai rerata 76 pengguna dalam setiap bulannya. Tokopedia yang digunakan oleh Karang Taruna ini terbukti mampu meningkatkan atensi pelanggan dan pada akhirnya melakukan pembelian. Hal ini pernah diungkapkan pada penelitian (Ramli et.al. 2019) bahwa ada perubahan atau pergeseran perilaku bisnis dalam hal penjualan dan pembelian barang. Perubahan tersebut dari konvensional $\mathrm{C} 2 \mathrm{C}$ ke arah digital $\mathrm{C} 2 \mathrm{C}$ maupun B2B. Hal ini juga dikuatkan dengan penelitian (Sholeh et.al. 2020) yang mengungkapkan bahwa penggunaan marketplace oleh UKM mampu meningkatkan pendapatan dan atensi pelanggan. Berikut ini adalah grafik pengguna marketplace dan omset dari marketplace:

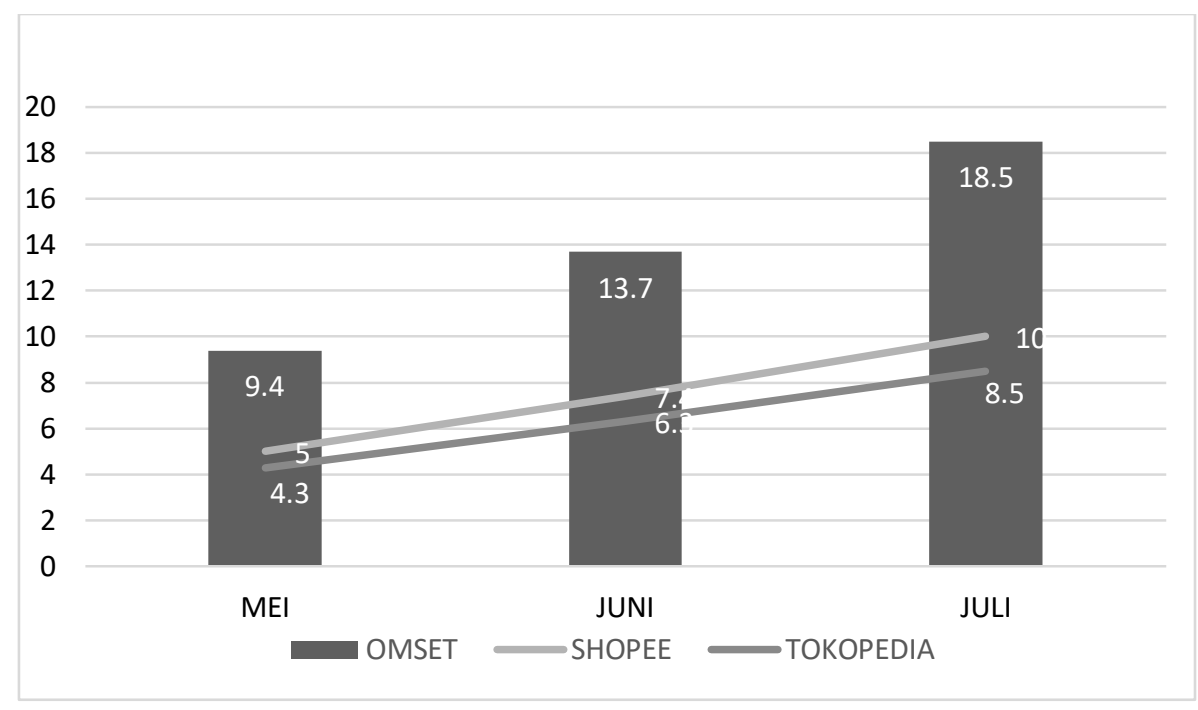

Grafik 4 Omset dan Pengguna Marketplace

Berdasarkan grafik di atas menunjukkan bahwa pelanggan Bisnis Karang Taruna Permata Alam Permai lebih banyak menggunakan Shopee untuk belanja dibandingkan Tokopedia. Namun perbedaan tersebut tidak signifikan hanya $46 \%$ menggunakan Tokopedia dan 54\% menggunakan Shopee. 


\section{Strategi Pemasaran}

Strategi Pemasaran online yang dilakukan oleh Karang Taruna Permata Alam Permai mempunyai beberapa tahapan yaitu pertama posting produk ke media sosial (Instagram, FaceBook) berupa highlight, dan story). Kedua, penjadwalan unggahan media sosial. Ketiga, menentukan jumlah posting unggahan per hari. Maksimal 10 unggahan setiap hari. Hal ini untuk menghindari postingan dianggap spam. Keempat, menentukan jangka waktu posting. Paling lama jangka waktu adalah 5 hari antar unggahan. Sementara itu dari sisi Pemasaran online ada beberapa hal yang telah dilakukan oleh Karang Taruna Permata Alam Permai, yaitu:

\section{Content Marketing}

Content marketing berkaitan erat dengan desain dan pesan yang akan disampaikan. Pesan dan desain harus mampu mengkomunikasikan pesan dan mudah dipahami oleh target pasar. Untuk itu pesan yang disampaikan adalah model membujuk target pasar agar tertarik untuk mengajukan pertanyaan atau bahkan langsung mengambil keputusan pembelian.

\section{Digital Promotion Copywriting}

Caption yang digunakan oleh Karang Taruna Permata Alam Permai dalam setiap unggahan ke media sosial menggunakan caption standar dan selalu memberikan informasi yang benar.

\section{Social Media Integration}

Integrasi yang dilakukan oleh Karang Taruna Permata Alam Permai adalah menmghubungkan antar media sosial. media sosial yang diintegrasikan adalah FaceBook dan Instagram. Sehingga segala unggahan keduanya mempunyai kesamaan dari foto maupun caption.

\section{Media Metric}

Fitur ini ada dalam perangkat instagram ketika menggubah akun biasa menjadi akun bisnis. Fungsi dari fitur ini adalah untuk mengetahui aktivitas antara lain interaction, profile visits, get direction, reach, dan impression.

Pengukuran dan Evaluasi

Kegiatan ini digunakan untuk mengukur sejauh mana penerapan yang dilakukan telah tepat sasaran. Selain itu kegiatan ini juga untuk mengukur elemen metric mana yang paling punya pengaruh. Sementara itu evaluasi digunakan untuk mendapatkan input atau masukan perbaikan dan pengembangan dari metode yang telah dilakukan.

Berikut ini adalah hasil metric pengukuran strategi Pemasaran: 
Tabel 2 Pengukuran Metric

\begin{tabular}{lll}
\hline No & Metric & Total \\
\hline $\mathbf{1}$ & Consumption & 2.550 \\
$\mathbf{2}$ & Retention & 1.340 \\
$\mathbf{3}$ & Sharing & 550 \\
$\mathbf{4}$ & Engagement & 601 \\
$\mathbf{5}$ & Lead & 1 \\
$\mathbf{6}$ & Sales & 1 \\
$\mathbf{7}$ & Production & 5 \\
\hline
\end{tabular}

Berdasarkan Tabel 2 di atas menunjukkan bahwa consumption merupakan metrics yang mempunyai nilai pengaruh paling besar terhadap Bisnis Karang Taruna Permata Alam Permai. Metrics tersebut terdiri atas page views, unique visitors, average time on page, email open, email click, dan form completion. Sementara itu metrics yang mendapatkan poin paling sedikit adalah Sales dan Production. Dengan demikian, Karang Taruna Permata Alam Permai harus meningkatkan aktifitas di metrics tersebut. Hal ini untuk semakin mendongkrak penjualan dan pendapatan dari bisnis tersebut.

\section{PENUTUP}

Berdasarkan hasil kegiatan PKM yang dilaksanakan di Desa Gedangan Sidoarjo dan Mitra Karang Taruna Permata Alam Permai telah berjalan dengan baik. Mitra telah mengaplikasikan media sosial dan marketplace sebagai bagian dari digital marketing tool. Penggunaan media ini mampu memberikan peningkatan pendapatan dari omset. Peningkatan penjualan ini tak lepas dari daya jangkau media tool yang digunakan lebih luas jika dibandingkan dengan model pemasaran konvensional. Meskipun beberapa pelaksanaan kegiatan harus mengalami perubahan pada praktiknya namun hal tersebut tidak mengubah substansi kegiatan. Perubahan ini juga terkait dengan masa pandemi Covid19. Pelaksanaan kegiatan pelatihan dan pendampingan yang sedianya dilaksanakan secara offline akhirnya dilaksanakan sepenuhnya dengan secara online.

Beberapa saran yang bisa diberikan pada kegiatan ini sebagai dasar kegiatan lanjutan adalah sebagai berikut: 1) Pengembangan dan pelatihan pembuatan video untuk content media social dan 2) Tips dan trik algoritma media sosial agar selalu menjadi trending.

\section{UCAPAN TERIMA KASIH}

Kegiatan ini dapat berjalan lancar dan memberikan kontribusi pada pengembangan wawasan masyarakat setempat karena adanya dukungan dari beberapa pihak. Ucapan terimakasih tim pelaksana PKM diberikan kepada pihak-pihak di bawah ini: 
1. Universitas Dinamika yang telah memberikan dukungan financial terhadap kegiatan ini.

2. Bagian P3M Universitas Dinamika atas dukungan administrasi perijinan selama pelaksanaan kegiatan.

3. Pengurus Karang Taruna Permaya Alam Permai, Gedangan Sidoarjo atas kesediaan menjadi mitra dalam kegiatan ini.

4. Pengurus RT Permata Alam Permai Gedangan Sidoarjo atas dukungan selama kegiatan.

5. Mahasiswa Undika (Tim Pelatihan) yang telah membantu sebagai asisten pemateri pelatihan selama kegiatan berlangsung.

6. Dan semua pihak yang telah membantu baik secara langsung maupun tidak langsung.

\section{DAFTAR PUSTAKA}

Akbar, S. I. (2018). Impact of Social Media Usage Activities on Brand Awareness of Young Consumers The era of BBC and The Times has changed because we no longer depend. İktisadi ve İdari Bilimler Fakültesi Dergisi, 1(33), 217-234.

Apriadi, D., \& Arie Yandi Saputra. (2016). E-Commerce Berbasis Marketplace Dalam Upaya Mempersingkat Distribusi Penjualan Hasil Pertanian. Jurnal RESTI, 20(12), 1684-1689. https://doi.org/10.3969/j.issn.2095-4344.2016.12.002

Asri, T. M., \& Megawati, F. (2018). Rancangan Dan Penerapan Promosi Melalui Media Sosial (Instagram) Di Ruang Baca Vokasi. Edulib, 8(2), 156. https://doi.org/10.17509/edulib.v8i2.9736

Barri, H. G., \& Saerang, D. P. E. (2017). The Impact of Viral Marketing Using Social Media Platforms on Brand Awareness (Case Study: Laneige Cosmetic). Jurnal EMBA: Jurnal Riset Ekonomi, Manajemen, Bisnis Dan Akuntansi, 5(3), 39453954. https://doi.org/10.35794/emba.v5i3.18253

Batee, M. M. (2019). Pengaruh Media Sosial Terhadap Keputusan Pembelian Di Toko Kaos Nias Gunungsitoli. Jesya (Jurnal Ekonomi \& Ekonomi Syariah), 2(2), 313324. https://doi.org/10.36778/jesya.v2i2.108

Fauziyah, F. (2018). Pemberdayaan UMKM Melalui Akun Organisasi Bisnis Berbasis ECommerce (Studi Kasus Pada Forum UKM KSRN Kabupaten Jember). Proceedings - PROGRESS, 1(1), 360-371.

Fianto, A. Y. A. (2020a). Satifaction As Intervening For The Antecedents Of Intention To Revisit: Marine Tourism Context In East Java. Relasi, 16(1), 179-207.

Fianto, A. Y. A. (2020b). The Antecedents of Purchase Decision for Hijab Fashion 
Products. Manajemen, 12(1), 154-165.

Hidayat, S., Suryantoro, H., \& Wiratama, J. (2017). Pengaruh Media Sosial Facebook Terhadap Perkembangan E-Commerce Di Indonesia. Simetris : Jurnal Teknik Mesin, Elektro Dan Ilmu Komputer, 8(2), 415. https://doi.org/10.24176/simet.v8i2.1165

Ikawira, E. Y., \& Fianto, A. Y. A. (2014). Penciptaan Buku Ilustrasi Legenda Reog Sebagai Upaya Mengenalkan Budaya Lokal kepada Anak-Anak. Art Nouveau, $3(1)$.

Intan, T., Revia, B., \& Erwita, A. (2019). Peningkatan daya saing produsen minuman herbal melalui pembuatan konten kreatif media sosial berbasis pemasaran emarketing. Jurnal Komunikasi Profesional, 3(2). https://doi.org/10.25139/jkp.v3i2.1982

Jafar, A., Fianto, A. Y. A., \& Yosep, S. P. (2014). Penciptaan Buku Ilustrasi Permainan Tradisional Sebagai Upaya Pelestarian Warisan Budaya Lokal. Art Nouveau, 3(1).

Lauwrentius, S. (2015). Penciptaan City Branding melalui Maskot sebagai Upaya untuk Mempromosikan Kabupaten Lumajang. Unpublished Undergraduate Thesis, Visual Communication Design.

Mbete, G. S., \& Tanamal, R. (2020). Effect of Easiness, Service Quality, Price, Trust of Quality of Information, and Brand Image of Consumer Purchase Decision on Shopee Online Purchase. Jurnal Informatika Universitas Pamulang, 5(2), 100. https://doi.org/10.32493/informatika.v5i2.4946

Pinasti, R. D., Fianto, A. Y. A., \& Hidayat, W. (2015). Penciptaan Buku Komik Sebagai Upaya Pengenalan Permainan Tradisional Kepada Remaja. Art Nouveau, 4(1).

Pradiani, T. (2017). Pengaruh Sistem Pemasaran Digital Marketing Terhadap Peningkatan Volume Penjualan Hasil Industri Rumahan. JIBEKA, 11(2), 46-53.

Puspitarini, D. S., \& Nuraeni, R. (2019). Pemanfaatan Media Sosial Sebagai Media Promosi. Jurnal Common, 3(1), 71-80. https://doi.org/10.34010/common.v3i1.1950

Ramli, Y., Firdaus, I., Arief, H., \& Setiawan, M. (2019). Mobile Marketplace As a Medium for Selling Micro Small Medium Enterprise Products. ICCD, 2(1), 55-59. https://doi.org/10.33068/iccd.vol2.iss1.209

Ratna Gumilang, R. (2019). Implementasi Digital Marketing Terhadap Peningkatan Penjualan Hasil Home Industri. Coopetition : Jurnal Ilmiah Manajemen, 10(1), 914. https://doi.org/10.32670/coopetition.v10i1.25 
Rudi Santoso, dkk.: Pemanfaatan Digital Marketing untuk Pengembangan Bisnis Pada Karang Taruna Permata Alam

Ridwan, M., Militina, T., \& Achmad, G. N. (2020). How Trust and Quality of Information Affect Buying Interest and Purchasing Decisions? (Study on Shopee Customers in Samarinda). International Journal of Economics, Business and Accounting Research (IJEBAR), 2020(1), 95-102.

Santoso, Rudi; (2019). Public Relation : Suatu Pengantar (1st ed.). Graha Ilmu.

Santoso, Rudi, \& Fianto, A. Y. A. (2020). Pengaruh Marketing Mix Produk Jasa terhadap Keputusan Berkunjung Wisata Bahari Jawa Timur. Kinerja, 17(1), 69-79.

Santoso, Rudi, Shinta, R., \& Fianto, A. Y. A. (2019). Pengaruh Bauran Pemasaran Jasa Terhadap Keputusan Berkunjung Ke Wisata Bahari Jawa Timur. Jurnal Manejemen Dan Bisnis, 4(2), 1-14.

Sholeh, M., Triyono, J., \& Rachmawati, R. Y. (2020). Pendampingan Kelompok Informasi Masyarakat Dengan Memanfaatkan Marketplace Sebagai Media Pemasaran. Jurnal Penelitian Dan Pengabdian Kepada Masyarakat UNSIQ, 7(2), 158-164. https://doi.org/10.32699/ppkm.v7i2.965

Sulaksono, J., \& Zakaria, N. (2020). Peranan Digital Marketing Bagi Usaha Mikro , Kecil , Dan Menengah ( UMKM ) Desa Tales Kabupaten Kediri. Generation Journal, $4(1), 41-48$.

Sunarti, S., Rachmawati, S., \& Handayanna, F. (2019). Peningkatan Pendapatan UKM Pada Hacord Gallery Dengan Aplikasi Web Marketplace E-Commerce. Jurnal Terapan Abdimas, 4(2), 166. https://doi.org/10.25273/jta.v4i2.4840

Susanto, A., Sari, C. A., Moses, D. R. I., Rachmawanto, E. H., \& Mulyono, I. U. W. (2020). Implementasi Facebook Marketplace untuk Produk UMKM sebagai Upaya Peningkatan Pemasaran dan Penjualan Online. Abdimasku : Jurnal Pengabdian Masyarakat, 3(1), 42. https://doi.org/10.33633/ja.v3i1.64

Tarigan, R., \& Tritama, H. B. (2016). The Effect of Social Media to the Brand Awareness of A Product of A Company. CommIT (Communication and Information Technology) Journal, 10(1), 9. https://doi.org/10.21512/commit.v10i1.904

Yulia, I. (2018). Optimalisasi Penggunaan Media Sosial Dalam Pemasaran Sosial dan Komunikasi Perubahan Perilaku (Suatu Pendekatan Studi Literature Review). Hearty, 6(2). https://doi.org/10.32832/hearty.v6i2.1276

Yuliana, O. Y. (2000). Penggunaan Teknologi Internet Dalam Bisnis. Jurnal Akuntansi Dan Keuangan, 2(1), 36-52. https://doi.org/10.9744/jak.2.1.pp.36-52 